ENVIRONMENTAL RESTORATION PROGRAM

\section{Bear Creek Valley Boneyard/Burnyard Accelerated Action Project Plan, Oak Ridge Y-12 Plant, Oak Ridge, Tennessee}

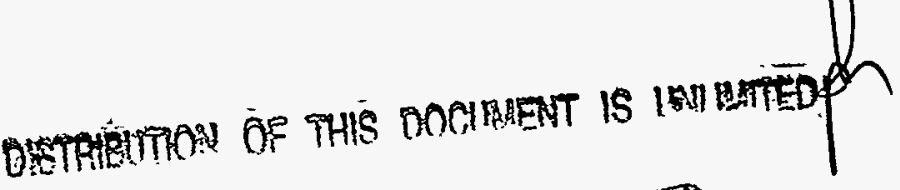

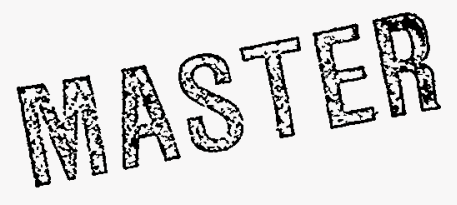

This document has been approved by the Y-12 Technical Information Office for release to the public. Date: $02 / 23 / 98$ 


\section{Science Applications International Corporation}

contributed to the preparation of this document and should not be considered an eligible contractor for its review. 


\section{Bear Creek Valley Boneyard/Burnyard Accelerated Action Project Plan, Oak Ridge Y-12 Plant, Oak Ridge, Tennessee}

Date Issued-February $1998^{\circ}$

Prepared by

Șcience Applications International Corporation Oak Ridge, Tennessee under subcontract 12B-99341C

Prepared for the

U.S. Department of Energy

Office of Environmental Management

under budget and reporting code EW 20

Environmental Management Activities at the

OAK RIDGE Y-12 PLANT

Oak Ridge, Tennessee 37831 managed by

LOCKHEED MARTIN ENERGY SYSTEMS, INC.

for the

U.S. DEPARTMENT OF ENERGY

under contract DE-AC05-84OR21400 


\section{DISCLAIMER}

This report was prepared as an account of work sponsored by an agency of the United States Government. Neither the United States Government nor any agency thereof, nor any of their employees, makes any warranty, express or implied, or assumes any legal liability or responsibility for the accuracy, completeness, or usefulness of any information, apparatus, product, or process disclosed, or represents that its use would not infringe privately owned rights. Reference herein to any specific commercial product, process, or service by trade name, trademark, manufacturer, or otherwise does not necessarily constitute or imply its endorsement, recommendation, or favoring by the United States Government or any agency thereof. The views and opinions of authors expressed herein do not necessarily state or reflect those of the United States Government or any agency thereof. 


\section{DISCLAIMER}

Portions of this document may be illegible electronic image products. Images are produced from the best available original document. 


\section{CONTENTS}

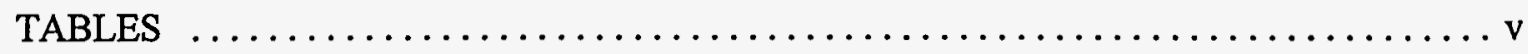

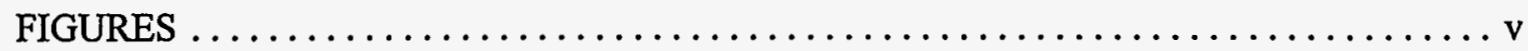

ABBREVIATIONS $\ldots \ldots \ldots \ldots \ldots \ldots \ldots \ldots \ldots \ldots \ldots \ldots \ldots \ldots \ldots \ldots \ldots \ldots \ldots \ldots \ldots \ldots$

EXECUTIVE SUMMARY $\ldots \ldots \ldots \ldots \ldots \ldots \ldots \ldots \ldots \ldots \ldots \ldots \ldots \ldots \ldots \ldots \ldots \ldots \ldots$

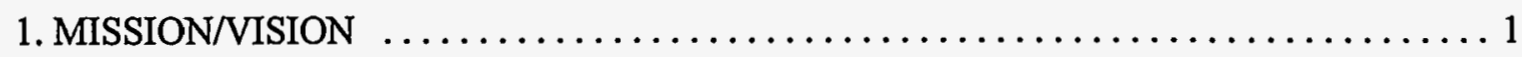

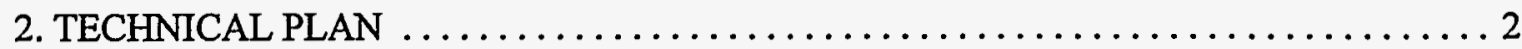

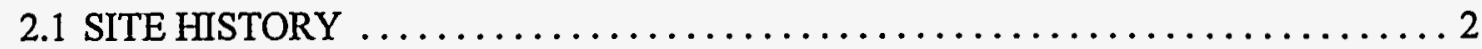

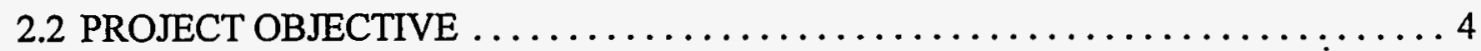

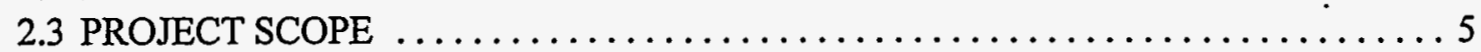

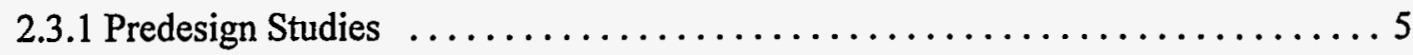

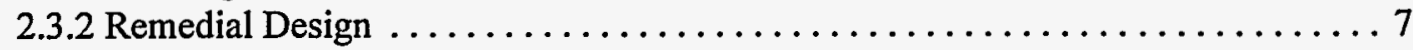

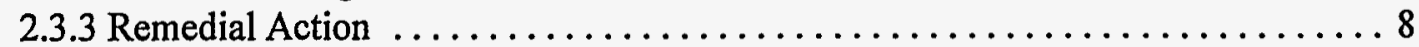

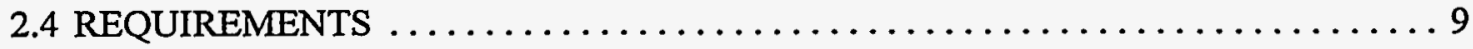

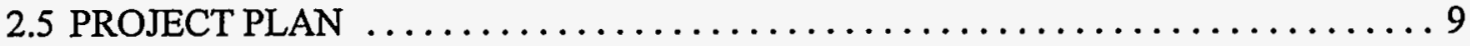

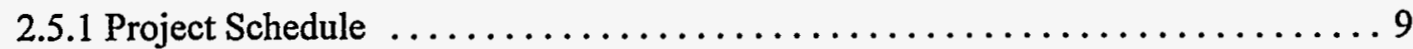

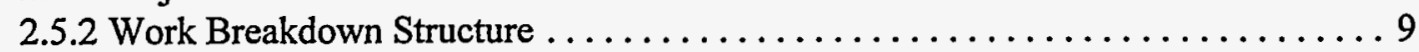

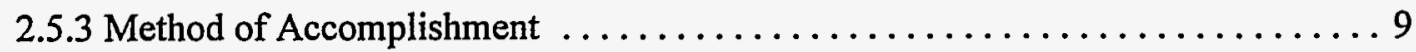

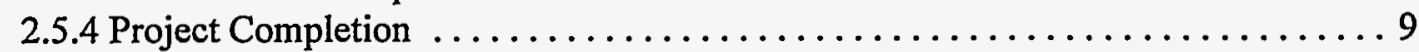

2.6 PUBLIC AND STAKEHOLDER INVOLVEMENT $\ldots \ldots \ldots \ldots \ldots \ldots \ldots \ldots \ldots$

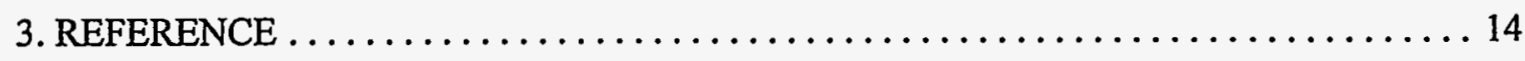




\section{TABLES}

1 Boneyard/Burnyard proposed remedial action method of accomplishment

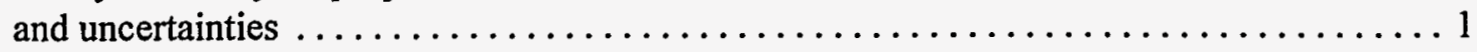

2 BCV Boneyard/Burnyard Accelerated Action Project team members . . . . . . . . . 14

\section{FIGURES}

1 Location of the Boneyard/Burnyard and the Hazardous Chemicals Disposal Area ....... 3

2 Timeline for the Boneyard/Burnyard Accelerated Action Project relative to the BCV

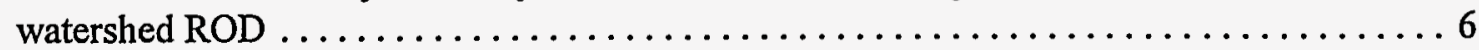

3 Project schedule for the BCV Boneyard/Burnyard Accelerated Action Plan . . . . . . . 10

4 Work breakdown structure for the BCV Boneyard/Burnyard Accelerated Action Project .. 13 


\section{ABBREVIATIONS}

$\begin{array}{ll}\text { BCV } & \text { Bear Creek Valley } \\ \text { CA } & \text { Characterization Area } \\ \text { CERCLA } & \text { Comprehensive Environmental Response, Compensation, and Liability Act } \\ \text { DOE } & \text { U.S. Department of Energy } \\ \text { DQO } & \text { data quality objectives } \\ \text { Energy Systems } & \text { Lockheed Martin Energy Systems, Inc. } \\ \text { EPA } & \text { U.S. Erivironmental Protection Agency } \\ \text { RAR } & \text { Remedial Action Report } \\ \text { RAWP } & \text { Remedial Action Work Plan } \\ \text { RCRA } & \text { Resource Conservation and Recovery Act } \\ \text { ROD } & \text { Record of Decision } \\ \text { TDEC } & \text { Tennessee Department of Environment and Conservation }\end{array}$


. 


\section{EXECUTIVE SUMMARY}

The mission of this early action project is to conduct field sampling to reduce uncertainties associated with remedial actions that remove uranium at the Boneyard/Burnyard, which is the source of contamination for groundwater and surface water in Bear Creek Valley, and to prepare an engineering document that defines the performance criteria upon which a competitive bid for remedial design and action can be based. 


\section{MISSION/VISION}

The mission of this early action project is to conduct field sampling to reduce uncertainties (listed in Table 1) associated with remedial actions that remove uranium at the Boneyard/Burnyard, which is the source of contamination for groundwater and surface water in Bear Creek Valley (BCV), and to prepare an engineering document that defines the performance criteria upon which a competitive bid for remedial design and action can be based.

Table 1. Boneyard/Burnyard proposed remedial action method of accomplishment and uncertainties

\begin{tabular}{llll}
\hline \multicolumn{1}{c}{ Activity } & \multicolumn{1}{c}{ Uncertainty } & \multicolumn{1}{c}{ Potential ramifications } & \multicolumn{1}{c}{ Cost } \\
impact
\end{tabular}

The following are specific elements of the Bear Creek Valley Boneyard/Burnyard Accelerated Action Project defined at the project scoping meeting held on December 9, 1997:

- Project Planning

- Project Plan

- Conceptual Model Meeting

- Predesign Studies

- Data Quality Objectives (DQO) Meeting

- Conduct predesign field investigation

- Characterization report 
- $\quad$ Remedial Action Work Plan (RAWP)

- Definition of performance criteria for the various components of the remedial action

- Description of the remedial action activities

- Schedule of activities

- Site requirements of various Project Plans (site-specific health and safety plan, waste management plan, and sampling and analysis plan)

- Remedial Design Report

- Develop design criteria for the project

- Describe the functions or operations to be performed

- List site preparations, conditions, removals, temporary roads, fencing, work areas, disposal areas, borrow areas, grading, drainage, utilities, and excavations

\section{TECHNICAL PLAN}

\subsection{SITE HISTORY}

The Oak Ridge Y-12 Plant, located within the Oak Ridge Reservation, is owned by the U.S. Department of Energy (DOE) and managed by Lockheed Martin Energy Systems, Inc. (Energy Systems). The Y-12 Plant is one of three major facilities on the Oak Ridge Reservation. The entire Oak Ridge Reservation was placed on the National Priorities List of Comprehensive Environmental Response, Compensation, and Liability Act of 1980 (CERCLA) sites in November 1989. Following CERCLA guidelines, sites within the reservation require a remedial investigation to define the nature and extent of contamination, evaluate the risks to public health and the environment, and determine the goals for a feasibility study of potential remedial actions.

The need to complete the remedial investigation/feasibility study process in a timely manner resulted in the establishment of watershed Characterization Areas (CAs) on the Oak Ridge Reservation, one of which is the BCV CA at the Y-12 Plant. The BCV CA consists of the area west of the Y-12 Plant defined by the watershed of Bear Creek. The watershed CA approach examines all the waste areas, groundwater, and surface water in a watershed and coordinates remediation activities in the context of managing the watershed as a single entity. The BCV CA is an operationally and hydrogeologically complex area that contains numerous contaminants and contaminant sources.

Characterization work for the $\mathrm{BCV} \mathrm{CA}$ remedial investigation identified the Boneyard/Burnyard (Fig. 1) as the main contributor of uranium in surface water and groundwater at the Integration Point in BCV. As part of the final remedy for the BCV Watershed, CERCLA actions proposed for the Boneyard/Burnyard include excavation of contaminated soils and waste materials where necessary, consolidation of contaminated surface soils and debris, disposal of contaminated material, and capping of the remainder of the site. This project will execute the designed planning for remedial action and the remedial actions for this proposed remedy at the Boneyard/Burnyard. 


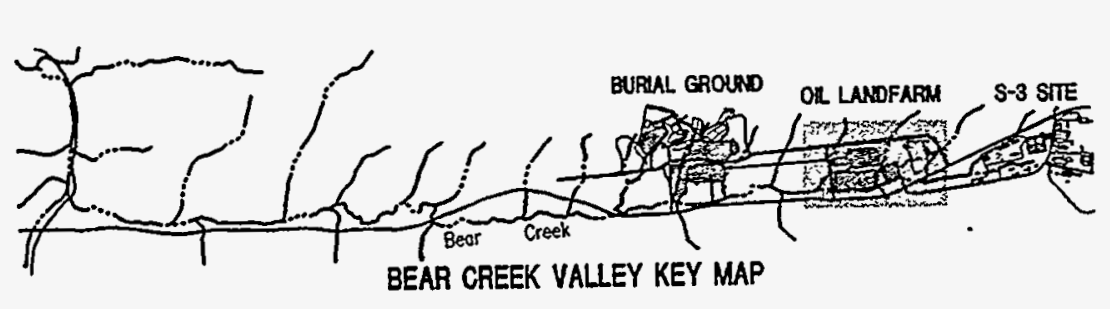

IEGEND:

.... MANAGEMENT BOUNDARY BEAR CREEK \&

GW-OOS . GROUNDWATER HEH

$\square$...... BONEYARD/BURNYARD

.. OIL LANDFARM RCRA CAP HAZARDOUS CHEMICALS

V777A ....... DISPOSAL AREA CAP

XXX SUSPECTED BURIED WASTE

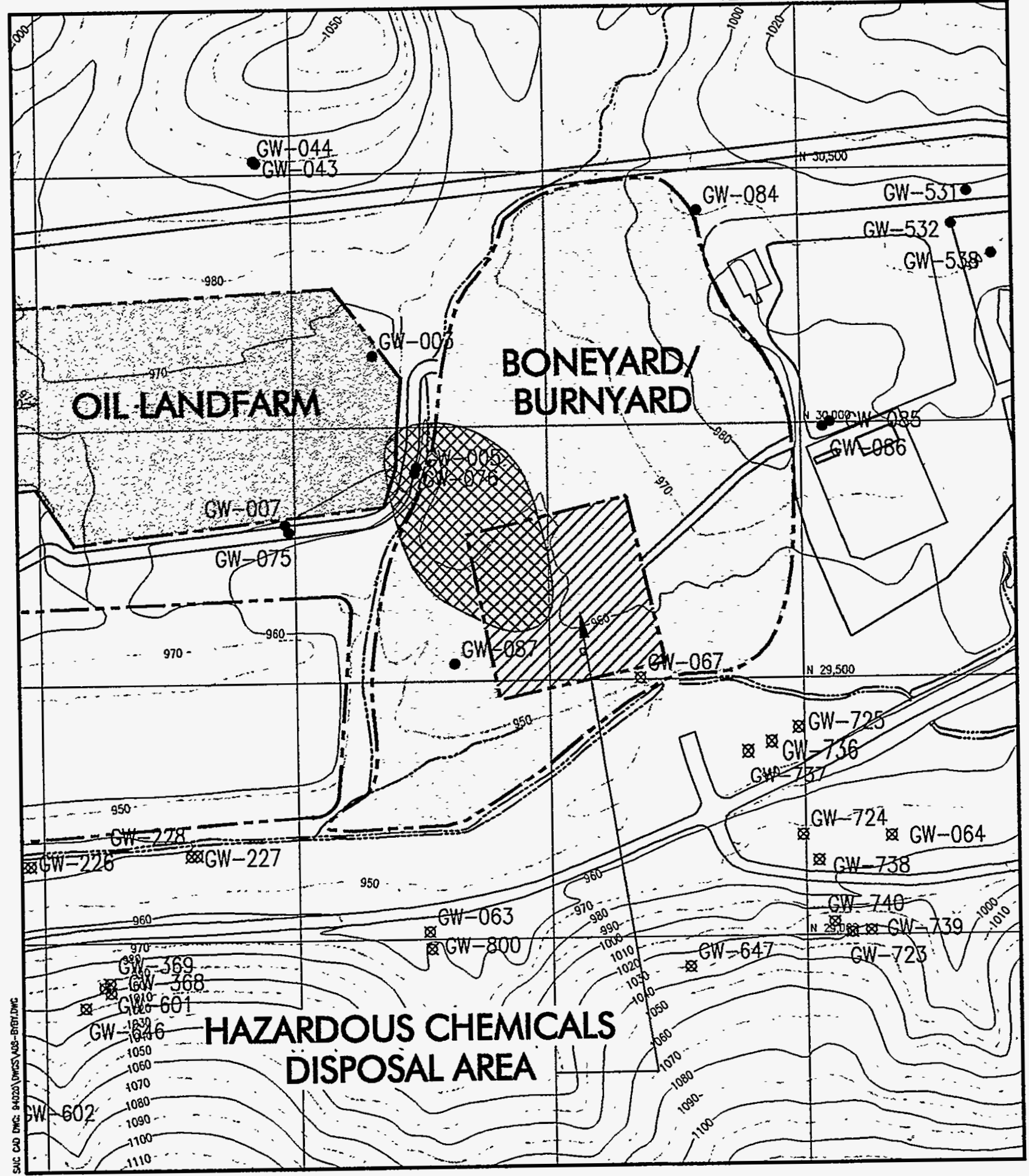

Fig. 1. Location of the Boneyard/Burnyard and the Hazardous Chemicals Disposal Area. 


\subsection{PROJECT OBJECTIVE}

The objective of this project is to reduce the flux of uranium in groundwater derived from the Boneyard/Burnyard site by excavating material at the Boneyard/Burnyard that is a source of uranium-contaminated leachate. The Boneyard/Burnyard is located north of Bear Creek Road, $\sim 1$ mile west of the main Y-12 Plant, and includes the former Hazardous Chemicals Disposal Area (Fig. 1). Combustible wastes and uranium waste were placed in trenches at the Boneyard/Burnyard and set on fire. The area was also used for abandoned equipment laydown. The Hazardous Chemicals Disposal Area is located in the interior of the Boneyard/Burnyard and is included in the Resource Conservation and Recovery Act(RCRA) Closure Plan for the Oil Landfarm with a capping closure.

The remedial investigation report for the BCV CA estimates that a total of $90,000 \mathrm{~m}^{3}$ of waste and contaminated soil are located in the Boneyard/Burnyard area; however, $\sim 7600$ to $15,000 \mathrm{~m}^{3}$ $\left(10,000\right.$ to $\left.20,000 \mathrm{yd}^{3}\right)$ of this material acts as a source for uranium contamination of groundwater and surface water. The following contaminants are frequently detected at the Boneyard/Burnyard: (1) in groundwater, uranium isotopes, mercury, beryllium, manganese, nickel, vanadium, tetrachloroethylene, trichloroethene, and 1,2-dichloroethene; (2) in surface water, uranium isotopes, mercury, and lithium; and (3) in soils, uranium isotopes, ${ }^{99} \mathrm{Tc}$, mercury, cadmium, copper, polyaromatic hydrocarbons, PCBs, and phthalates.

Uranium in soils and waste materials leaches to groundwater, which subsequently discharges to surface water in NT-3. Uranium in groundwater that has leached from buried waste and fill material at the Boneyard/Burnyard also migrates directly to the Maynardville Limestone and Bear Creek via shallow groundwater flow. According to the watershed remedial investigation report, the Boneyard/Burnyard site currently contributes $50-60 \%$ of the potential risk and chemical hazard at the watershed Integration Point through release of uranium. Excavation and capping of the contaminated soils and waste materials at the Boneyard/Burnyard that are leaching uranium to groundwater and surface water will reduce the production of leachate and contaminant migration into NT-3, Bear Creek, and the Maynardville Limestone.

This project consists of the following tasks:

- Engineering and predesign studies: Activities include sampling and analysis of soils and groundwater to provide a detailed estimate of the volume of waste material for excavation and the chemical characteristics relative to waste acceptance criteria.

- Remedial design: Activities include preparing the necessary engineering plans and specifications to implement the project and issuing a combined Remedial Design Report/Remedial Action Work Plan. Design documents also include construction specifications, cost assessments, and a schedule.

- Remedial action: Activities include conducting the selected remedial action and preparing the Remedial Action Report, which summarizes the project history, describes the construction activities, and explains operation/maintenance/monitoring required.

The project began in January 1998 with development of the planning documents for the engineering and predesign studies. The schedule of this project depends on completion and approval of the Bear Creek Watershed Record of Decision (ROD), with this being the first action 
implemented under the ROD (Fig. 2). On the basis of the current schedule for the ROD, this project will be complete when the Remedial Action Report is completed and issued to the regulators for approval in May 2002. The following milestones will be completed during the course of the project:

- Submit Draft Remedial Action Work Plan to DOE for comment

- Submit Draft Remedial Design Report to DOE for comment

- SubmitDraftRemedial Action Work Plan to U.S. Environmental Protection Agency (EPA) and Tennessee Department of Environment and Conservation (TDEC) for comment

- Submit Final Remedial Action Work Plan to EPA/TDEC for approval

- Submit Draft Remedial Action Report to DOE for comment

- Submit Draft Remedial Action Report to EPA/TDEC for comment

- Submit Final Remedial Action Report to EPA/TDEC for approval

This project plan addresses the technical objectives, system requirements, regulatory strategy, work breakdown structure, schedule, and documentation for completion of the BCV Boneyard/Burnyard Accelerated Action Project.

\subsection{PROJECT SCOPE}

\subsubsection{Predesign Studies}

\subsubsection{Project planning}

The scope of the BCV Boneyard/Burnyard Accelerated Action was determined at the Project Scoping meeting held on December 9, 1997. The Project Plan is based on the meeting minutes that outline the scope for this early action and define the project team, roles and responsibilities for the project team, the project schedule, key milestones, and regulatory requirements for the $\mathrm{BCV}$ Boneyard/Burnyard Accelerated Action Project.

\subsubsection{DQO meeting}

Sampling for the characterization phase of this project will be optimized using the DQO process (EPA 1993). The project team will meet to define the DQOs for this action. The DQOs will define the requirements for sampling and analysis at the Boneyard/Burnyard that will satisfy the need to make decisions concerning design of the selected remedial alternative for this site.

\subsubsection{Field work documentation}

The meeting minutes from the DQO meeting will constitute a sampling and analysis plan for the characterization phase. This document will define the number of samples, their locations and sample procedures, analyte lists, detection limits, and accuracy requirements for the characterization effort. 


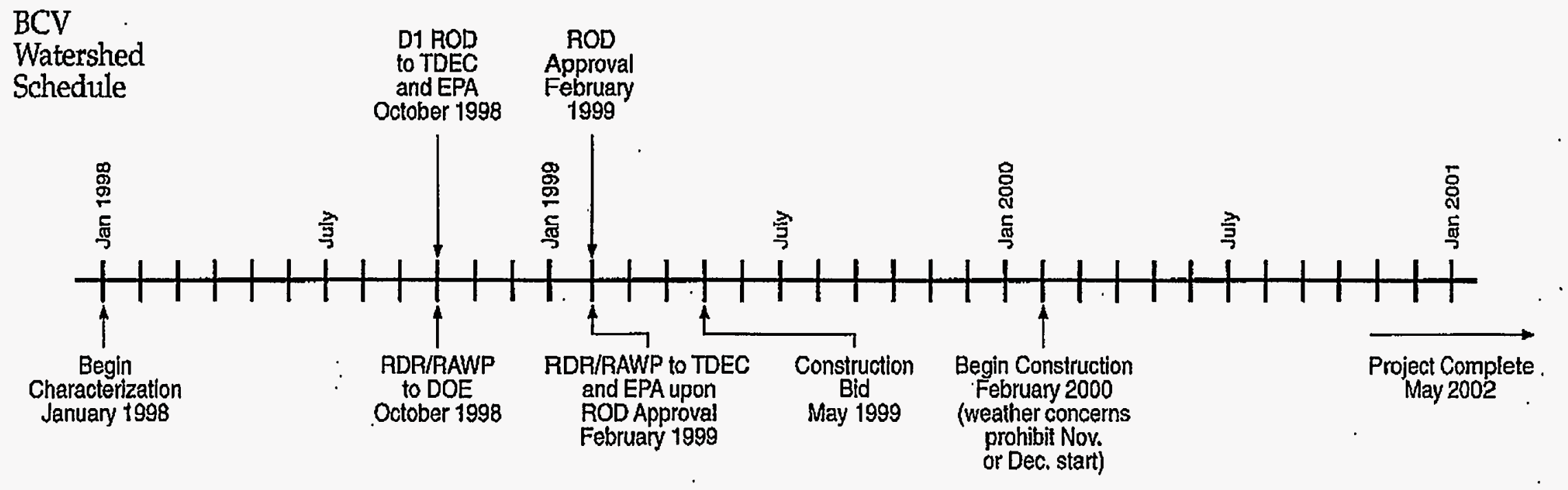

$a$

Fig. 2. Timeline for the Boneyard/Burnyard Accelerated Action Project relative to the BCV watershed ROD. 
The Y-12 Waste Management Checklist and Health and Safety Checklist will be completed. These will constitute the characterization phase waste management plan and health and safety plan. In addition, a quality assurance project plan, and data management plan will be completed.

\subsubsection{Characterization field work}

Characterization field work will be conducted following the sampling and analysis plan and according to the health and safety plan and quality assurance project plan. Field work may include performing walkover radiological surveys, characterizing surface debris, creating a detailed site description, sampling and analyzing soils and subsoils, and surveying. Any waste produced from characterization (e.g., personnel protective equipment, unused samples) will be disposed of according to the waste management plan. Analytical results and field observations will be managed following the data management plan.

\subsubsection{Characterization report}

The characterization report will include evaluation of the characterization data. The document will be produced in a preliminary draft form for review by DOE and the project team on June 26,1998 , and following an accelerated review by DOE (1 week), the final draft will be completed on July 14, 1998.

\subsubsection{Remedial Design}

\subsubsection{RAWP}

The RAWP will include a description of the remedial action activities, a schedule of activities, and site requirements of various project plans (site-specific health and safety plan, waste management plan, and sampling and analysis plan). The RAWP will also define the performance criteria for the various components of the remedial activities and will include a preliminary description of operation and maintenance activities. The document will be produced in a preliminary draft form for review by DOE and the Project Team. The document will be issued for DOE and regulatory approval in the form of D1 and D2 submittals. The D1 draft of the RAWP will be submitted to the regulators in February 1999 or upon approval of the BCV watershed ROD.

\subsubsection{Remedial Design Report}

In conjunction with preparing the RAWP, the Remedial Design Report will be prepared. The Remedial Design Report will be used by the management and integration contractor to develop a construction bid package for issuance to potential construction contractors. The report will contain design criteria for the project and will include the following information:

- a description of the functions or operations to be performed;

- existing site conditions;

- $\quad$ site preparations, conditions, removals, temporary roads, fencing, work areas, disposal areas, borrow areas, grading, drainage, and excavations;

- utilities, existing and proposed; 
- $\quad$ special security, environmental, safety, and health requirements; and

- $\quad$ permit requirements.

\subsubsection{Remedial Action}

\subsubsection{Implementation of remedial action}

Activities include conducting the selected remedial action. Remedial action will start after approval of the RAWP. Remedial activities are currently scheduled to start on May 5, 1999, with construction activities starting on February 7, 2000. The specific activities under this work breakdown structure are as follows:

- Design. Detailed design for the remedial action, including Title I and II design-related activities, resulting in an approved certification for a construction design package to be used as the basis for remedial activities.

- Confirmatory sampling and monitoring. Soil sampling at this stage will also be used to confirm excavation of contaminated soils to performance criteria. In addition, sampling at this time will confirm soil chemical characteristics with respect to waste disposal criteria. Monitoring of surface water in nearby NT-3 and Bear Creek will be conducted during the remedial action.

- Soil excavation. This task includes excavation of $\sim 7600$ to $15,000 \mathrm{~m}^{3}\left(10,000\right.$ to $\left.20,000 \mathrm{yd}^{3}\right)$ of contaminated soil with uranium concentrations near $100 \mathrm{ppm}$. In addition, $<760 \mathrm{~m}^{3}$ $\left(1000 \mathrm{yd}^{3}\right)$ of low-level ( $<5 \mathrm{ppm}$ uranium) surface soils and debris on the Bear Creek floodplain will be excavated.

- Waste Disposal. The contaminated soils and $\sim 3.8 \mathrm{~m}^{3}\left(5 \mathrm{yd}^{3}\right)$ of construction debris (low-level waste at $1 \mathrm{ppm}$ uranium) will be disposed of in the new Environmental Management Waste Management Facility (if available) or another suitable approved facility. Soils will be treated on-site, when necessary, before disposal. In addition, $7.6 \mathrm{~m}^{3}\left(10 \mathrm{yd}^{3}\right)$ of sanitary construction debris and personal protective equipment will be disposed of in Sanitary Landfill V. It is assumed that the excavated soils will meet the RCRA land disposal restrictions.

A 1-ha (2.5-acre) dewatering bed will be constructed and will include $1380 \mathrm{~m}^{3}\left(1800 \mathrm{yd}^{3}\right)$ of soil, $7650 \mathrm{~m}^{2}\left(10,000 \mathrm{yd}^{2}\right)$ of High Density Polyethylene liner, a $20.3-\mathrm{cm}$ (8-in.) clay layer $1850 \mathrm{~m}^{3}$ $\left(2400 \mathrm{yd}^{3}\right)$, a $20.3-\mathrm{cm}\left(8-\mathrm{in}\right.$.) gravel layer $1850 \mathrm{~m}^{3}\left(2400 \mathrm{yd}^{3}\right)$, and a water collection system.

\subsubsection{Remedial Action Report}

Activities include preparing the Remedial Action Report (RAR), which summarizes the project history, describes the construction activities, and explains operation/maintenance/monitoring required. The RAR will be prepared upon completion of the remedial action and will document compliance with the Remedial Action Work Plan, including performance criteria and any deviations. The RAR will be issued for DOE and regulatory approval in the form of D0, D1, and D2 submittals. RAR will be submitted to DOE for review on August 14, 2001, with submittal to the regulators on November 1, 2001. 


\subsection{REQUIREMENTS}

The Project Team will comply with the requirements of applicable laws and regulations and applicable requirements of DOE orders. At the removal action stage, requirements and laws such as the National Environmental Policy Act, the National Pollution Discharge Elimination System, DOE orders, and industrial hygiene will be identified in a best management practices plan, which will also define the regulatory strategy for the remedial action. The strategy for compliance with requirements at the characterization stage will be contained in the waste management plan, health and safety plan, and the quality assurance project plan for the characterization.

\subsection{PROJECT PLAN}

\subsubsection{Project Schedule}

The project schedule is shown in Fig. 3.

\subsubsection{Work Breakdown Structure .}

The BCV Boneyard/Burnyard Accelerated Action is a level-6 project within a Project-Baseline Summary (OR 42102) of Major System Acquisition-1, work breakdown structure element 01.20.01.04. The task has been further subdivided into work breakdown structure elements for predesign studies (10); remedial design (20), including the RAWP and Remedial Design Report; and the remedial action, including the RAR (40) (Fig. 4).

\subsubsection{Method of Accomplishment}

Primary roles and responsibilities within the BCV Boneyard/Burnyard Accelerated Action Project are assigned by the work breakdown structure: Energy Systems, and the management and integration successor, is responsible for predesign studies (10), remedial design (20), and the remedial action (40). Energy Systems employs various subcontractors in roles that include planning and management, characterization, document preparation, and construction. It is anticipated that the remedial action will be contracted as a single award including detailed design for the construction package, confirmatory sampling and monitoring, soil excavation, waste disposal, and the remedial action report.

The current multidisciplinary project team represents various entities. The primary responsibility for each team member is to provide support to other team members. See Table 2 for a list of current team members.

\subsubsection{Project Completion}

This project will be completed when an appropriate remedial action has been safely implemented and the RAR has been submitted. 


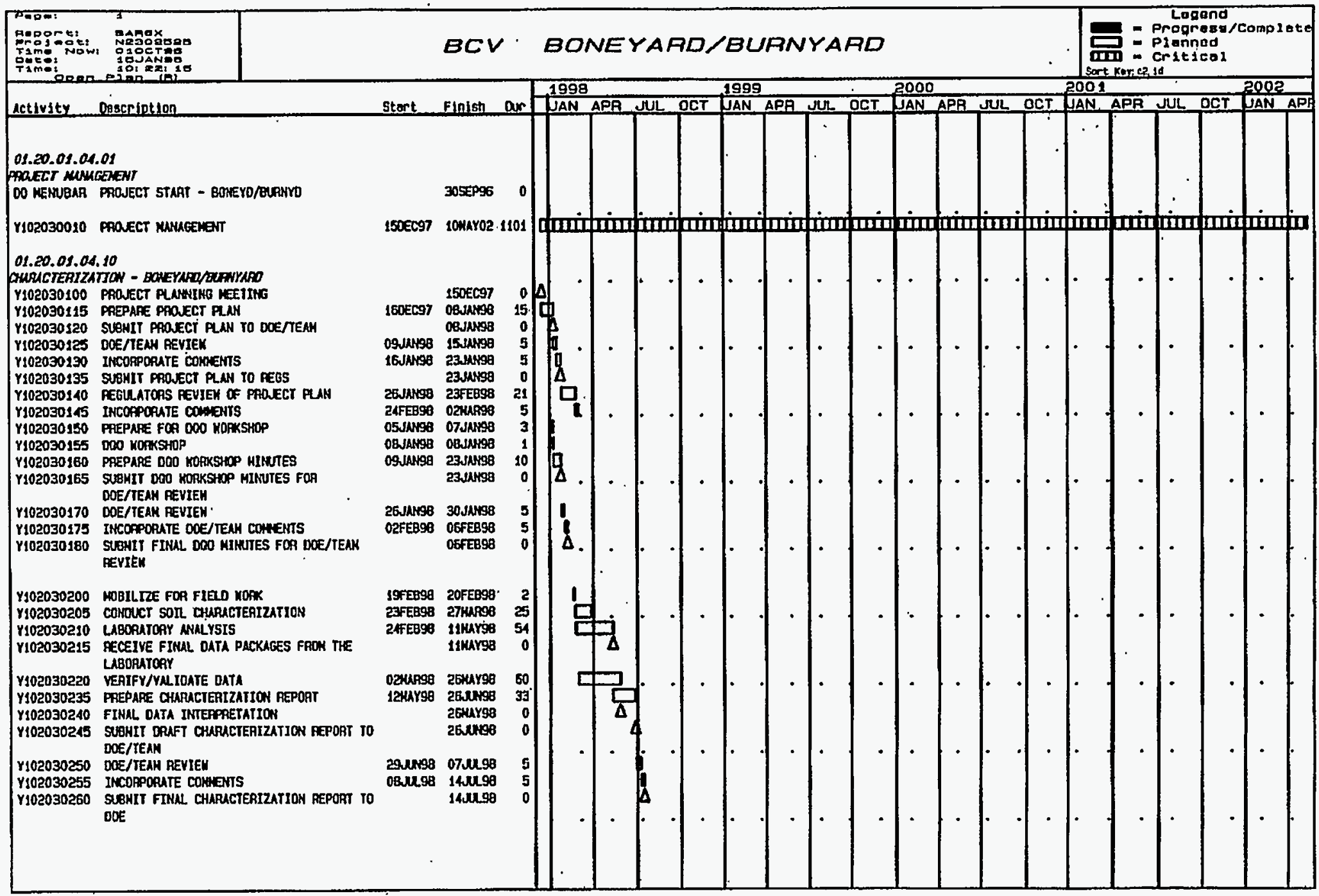

Fig. 3. Project schedule for the BCV Boneyard/Burnyard Accelerated Action Plan. 


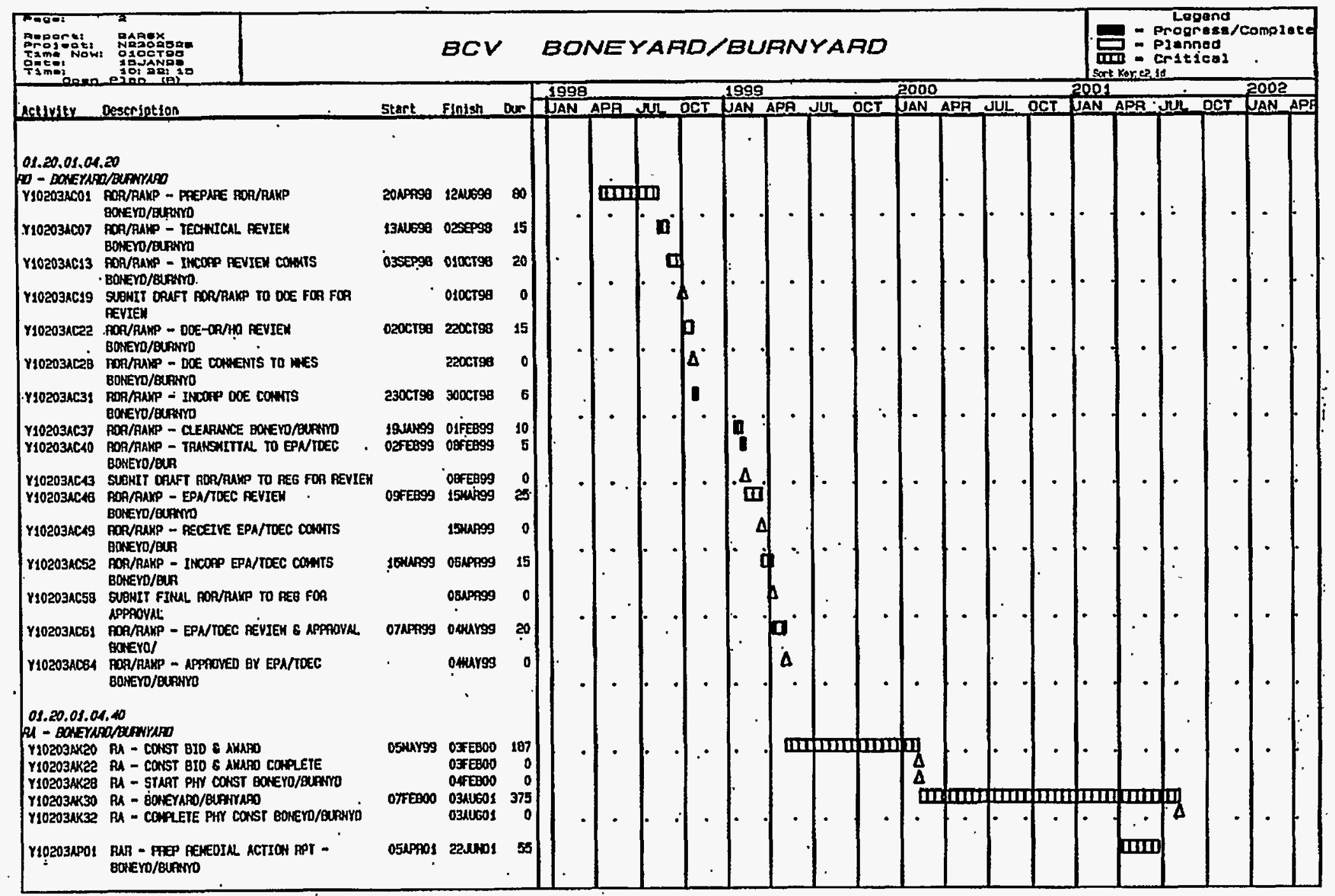

Fig. 3 (continued) 


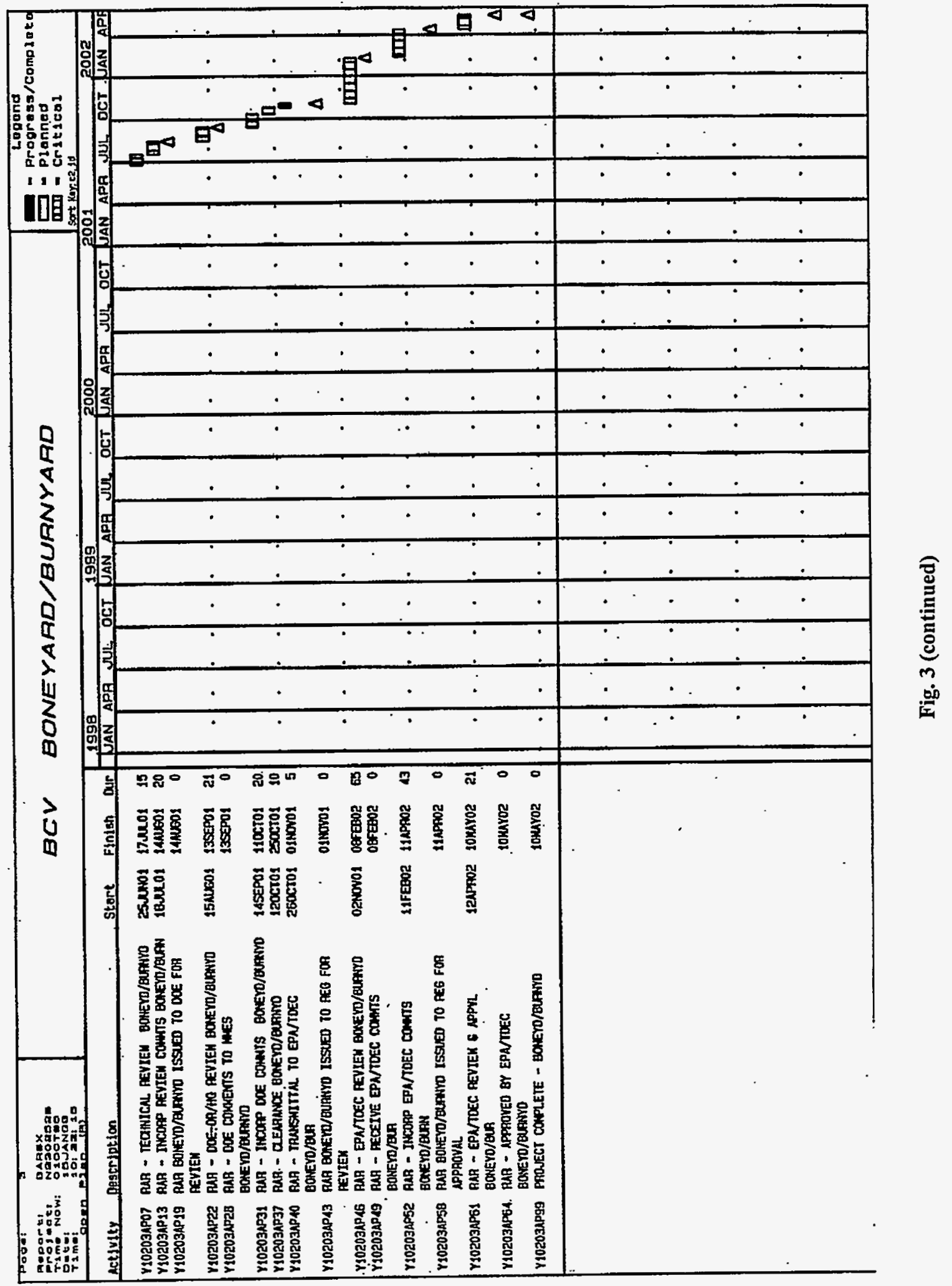




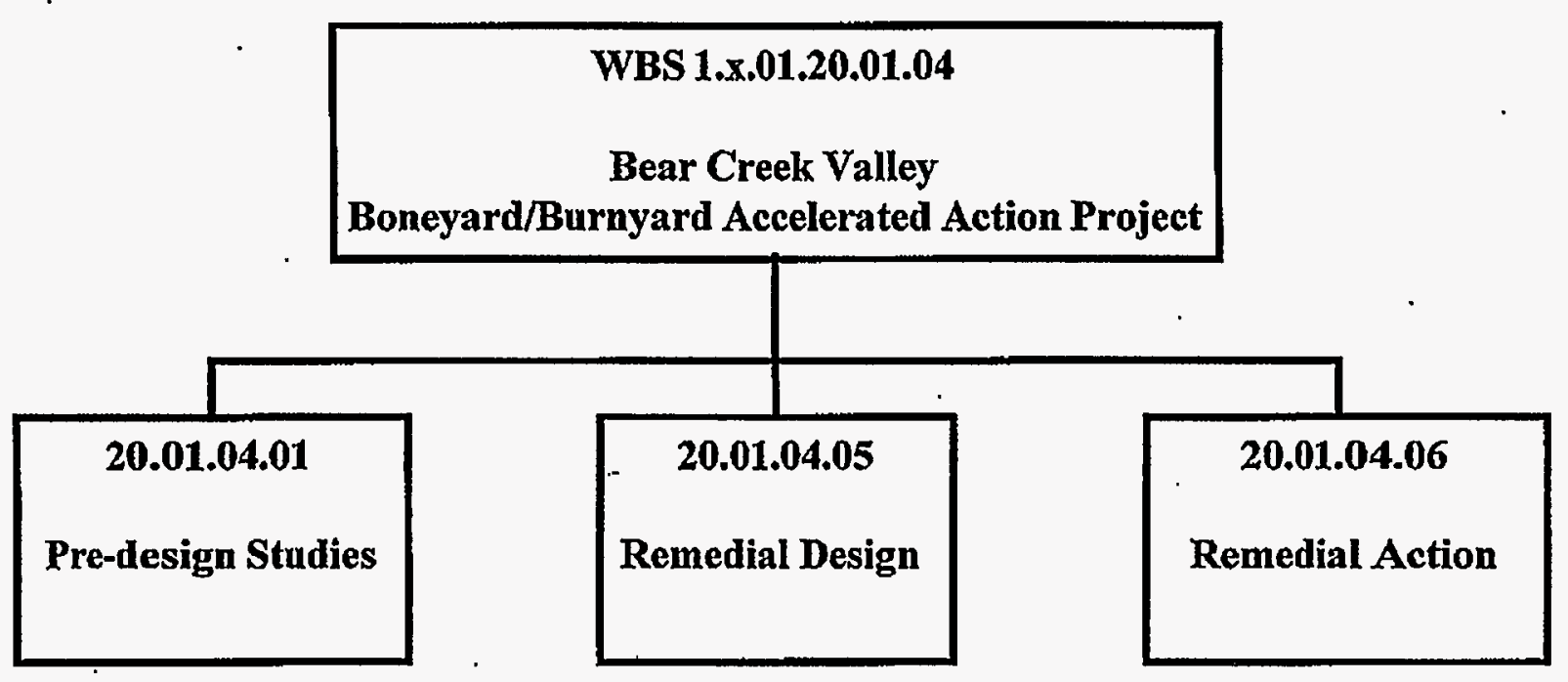

Fig. 4. Work breakdown structure for the BCV Boneyard/Burnyard Accelerated Action Project. 
Table 2. BCV Boneyard/Burnyard Accelerated Action Project team members

\begin{tabular}{llll}
\hline \multicolumn{1}{c}{ Name } & \multicolumn{1}{c}{ Organization } & $\begin{array}{c}\text { Telephone } \\
\text { number }\end{array}$ & \multicolumn{1}{c}{ E-mail address } \\
\hline Jerry Archer & Jacobs EM Team & $220-4719$ & jarcher@gmgw.com \\
Jason Darby & DOE-ORO & $241-6343$ & darbyjd@oro.doe.gov \\
Linda Houlberg & LMER & $574-7763$ & lih@ornl.gov \\
Tom Nakamoto & Energy Systems/PLX & $241-4906$ & nko@ornl.gov \\
Virginia Forsberg & LMER/ER & $574-7000$ & vmf@ornl.gov \\
Joe Pacelli & Jacobs & $220-4975$ & \\
Steve Kucera & Jacobs & $220-4907$ & stephen.kucera@jacobs.com \\
Michael Cox & Energy Systems Safety & $574-8398$ & coxma@ornl.gov \\
John H. Vanderlan & Energy Systems & $576-2745$ & jhv@ornl.gov \\
Wayne Human & Energy Systems & $574-0958$ & humanbw@ornl.gov \\
Karen Catlett & DOE-ORO & $241-2224$ & catlettk@oro.doe.gov \\
Duncan Moss & SAIC & $481-4752$ & philip.d.moss@cpmx.saic.com \\
Greg Schank & SAIC & $481-8760$ & gregory.f.schank@cpmx.saic.com \\
\hline
\end{tabular}

DOE-ORO = U.S. Department of Energy-Oak Ridge Operations Office; LMER = Lockheed Martin Energy Research Corporation; ER = Environmental Restoration; SAIC = Science Applications International Corporation.

\subsection{PUBLIC AND STAKEHOLDER INVOLVEMENT}

The goal of the Environmental Management Community Relations Program is to involve local stakeholders in an open and accessible decision-making process that identifies issues and alternatives during the planning and development stages of projects. This involvement is expected to lead to a mutually agreed-upon action plan that addresses public values and concerns and is technically feasible, environmentally sound, and safety- and health-conscious.

\section{REFERENCE}

EPA (U.S. Environmental Protection Agency) 1993. Guidance for the Data Quality Objective Process, EPA QA/G-4, U.S. Environmental Protection Agency Quality Assurance Management Staff, Washington, D.C. 


\section{DISTRIBUTION}

1. C. S. Haase

2. P. T. Owen

3. L. B. Raulston

4. File-EMEF DMC-RC

5. P. D. Moss, Science Applications International Corporation, 800 Oak Ridge Turnpike, $10^{\text {th }}$ Floor, Oak Ridge, TN 37830

6. A. K. Phelps, Bechtel Jacobs Company, 151 Lafayette Drive, P.O. Box 350, Oak Ridge, TN 37830 